Vol. 17 (2008): 278-288.

\title{
Impact of selenium enrichment on seed potato tubers
}

\author{
Marja Turakainen $^{1 *}$, Helinä Hartikainen ${ }^{2}$, Tytti Sarjala ${ }^{3}$ and Mervi M. Seppänen ${ }^{1}$ \\ ${ }^{1}$ Department of Applied Biology, PO Box 27, FI-00014 University of Helsinki, Finland. \\ Current address: Harjun oppimiskeskus, Katariinankuja 19, FI-49980 Ravijoki, Finland, \\ ${ }^{2}$ Department of Applied Chemistry and Microbiology, PO Box 27, FI-00014 University of Helsinki, Finland \\ ${ }^{3}$ Finnish Forest Research Institute, Parkano Research Unit, FI-39700 Parkano, Finland \\ *e-mail: turakainen@harjunopk.fi
}

\begin{abstract}
The aim of this study was to investigate the effect of Se enrichment on the growth of sprouts and growth vigour of seed potatoes (Solanum tuberosum L.) stored for 2 to 8 months. Our results showed that Se did not affect the duration of dormancy. At the high addition levels ( 0.075 and $0.9 \mathrm{mg} \mathrm{kg}^{-1}$ quartz sand), Se had some positive effects on the growth of sprouts. The peak sprouting capacity was reached after 8 months of storage. The highest Se enrichment of tubers had some positive effect on the free putrescine content in sprouts. However, the better growth of sprouts was not consistent with the growth vigour of the seed tubers and yield produced. Selenium had no significant effect on the malondialdehyde (MDA) or on the concentration of soluble sugars and starch. No significant effect of added Se on the early growth, stem and tuber numbers and yield parameters was observed. Irrespective of the level of Se added, the highest yield was harvested from plants produced with seed tubers stored for 6 months. Our results indicate that Se had some positive effects on the growth of sprouts, but it had no consistent effect on the growth vigour of seed tubers.
\end{abstract}

Key-words: growth vigour, seed potato tuber, selenium, Solanum tuberosum L., sprouting capacity, yield

\section{Introduction}

Potato (Solanum tuberosum L.) tubers are usually endodormant at time of harvest: they do not sprout, even under ideal conditions, within a time period of about 2 weeks (Hartmans and van Loon 1987). Dormancy is the physiological state of the tuber in which autonomous sprout growth will not occur within a reasonable period of time (usually two weeks) even when the tuber is kept in conditions optimal for sprout growth (Van Ittersum 1992, Struik and Wiersema 1999). The cultivar and, to some extent, the growing conditions during tuber development affect the duration of dormancy (Burton 1989). After the tuber has lost its apical 
Vol. 17 (2008): 278-288.

dominance, a physiologically young seed tuber exhibits strong apical dominance and at this stage only one or two main stems will develop (Struik and Wiersema 1999).

Physiological age of a potato tuber can be defined as the physiological stage of development of a seed tuber, which changes progressively with increasing chronological age, and is modified by growth history and storage conditions (Struik and Wiersema 1999). Physiological age of seed tuber affects emergence, canopy structure, number of stems per plant, number of tubers per stem, tuber size distribution and crop yield (Van Ittersum 1992, Struik and Wiersema 1999, Asiedu et al. 2003). The storage duration and conditions factors during storage, i.e. temperature, relative humidity; and diffuse light, affect the physiological age of seed tuber (Struik and Wiersema 1999). Depending on cultivar, these factors may have specific effects (van der Zaag and van Loon 1987, Hartmans and van Loon 1987, Van Ittersum 1992). Moreover, Knowles and Knowles (1989) and Kumar and Knowles (1993) showed that increased oxidative stress and consequent enhanced lipid peroxidation in tubers play an important role in the ageing processes.

Growth vigour is defined as the ability of a tuber to produce well-developed plants in a relatively short period of time under favourable growth conditions (van der Zaag and van Loon 1987, Hartmans and van Loon 1987, Struik and Wiersema 1999). Planting seed tubers of optimal physiological age for given growing conditions results in optimal plant establishment, plant growth and early yields (Knowles and Botar 1992, Asiedu et al. 2003). The length of growing season is only 140-180 days in Finnish potato production areas. Therefore, in most cases seed tubers are harvested when immature, and the tubers are considered to be physiologically very young. Therefore, in areas with short growing season, seed tubers are usually physiologically aged through sprouting them prior to planting ( $\mathrm{Ku}-$ mar and Botar 1992, Asiedu et al. 2003).

Physiological age of tubers is affected by the accumulation of sugars depending greatly on the effect of storage environment, the chronological age and respiration rate of tubers (Cottrell et al. 1993, Spychalla and Desborough 1990). Moreover, respiration rate of seed tuber depends on how far sprouting has progressed (Mikitzel and Knowles 1989a, Kumar and Knowles 1996). During prolonged storage, increased peroxidative damage-to the amyloplast membrane (Knowles and Knowles 1989, Kumar and Knowles 1993) and enhanced membrane permeability lead to senescent sweetening of potato tubers (Spychalla and Desborough 1990). Therefore, the accumulation of reducing sugars is used as a biochemical indicator to estimate the rate of physiological ageing of tubers (Kumar and Knowles 1993). However, no analytical methods are available to predict the extent of physiological ageing. This reaction pattern has been gauged using the physiological age index (PAI) (Caldiz et al. 2001), accumulated temperature sum (O'Brien et al. 1983) and storage temperature sum (Struik and Wiersema 1999).

The most common polyamines, spermine and spermidine, and their precursor putrescine are essential for normal growth and development of plants (Martin-Tanguy 2001). Their metabolism has been shown to respond to stress-related processes (Bouchereau et al. 1999). In the potato plant polyamines are involved in developmental processes, including sprout growth (Kaur-Sawhney et al. 1982) and tuberization (Mikitzel and Knowles 1989b).

Selenium is an essential microelement for antioxidative system of humans and animals (Schwartz and Foltz 1957, Rotruck et al. 1973, Gladyshev and Hatfield 1999). The physiological function of Se in higher plants is still unknown and needs to be clarified. Most cultivated plants have low ability to tolerate Se. Generally crop plants contain Se less than $25 \mu \mathrm{g} \mathrm{g}^{-1}$ dry weight (DW) (White et al. 2004, Rani et al. 2005). In this regard, potato is classified as a Se non-accumulator plant. Even though higher plants are thought not to require Se, there are increasing indications that at low concentrations, Se acts as an antioxidant and can promote plants growth and strengthen the capacity of plants to resist the oxidative stress caused by reactive oxygen species produced by internal biochemical reactions and external factors (Hartikainen and Xue 1999, Hartikainen et al. 2000, Xue and Hartikainen 2000, Xue et al. 2001, Pennanen et al. 2002, Seppänen et al. 2003, Djanaguiraman et al. 2005, Kong et al. 
Turakainen, M. et al. Impact of selenium enrichment on seed potato tubers

2005), whereas at higher concentrations it acts as a pro-oxidant inducing oxidative stress and reducing the yields (Hartikainen et al. 2000, Cartes et al. 2005). Previous studies have shown that added Se will be efficiently absorbed by leaves of potato plants and transported to the tubers (Turakainen et al. 2004a, b, 2006), and it is transferred from seed tubers to the tubers of next progeny (Turakainen et al. 2006). The storage for $2-8$ months did not affect the Se concentrations in the tubers (Turakainen et al. 2006). Additionally, in tubers Se is found to allocate in the organic fraction providing evidence that it is incorporated into proteins (Turakainen et al. 2006). Moreover, Se has a beneficial effect on tuber yield and it improves the processing quality of tubers (Turakainen et al. 2004a,b, 2006). In senescing plants, the added Se delayed the senescence (Xue et al. 2001, Djanaguiraman et al. 2005) and stimulated plant growth as well as diminished lipid peroxidation by increasing the antioxidative capacity of plants (Xue et al. 2001). On the basis of the antioxidative function of Se, it is possible that Se may improve antioxidative capacity of seed tubers and delay their physiological ageing. This research was undertaken to study whether Se able is to retard the physiological ageing of potato tubers and maintain or improve their growth vigour.

\section{Material and methods}

\section{Plant material and experimental design}

The tubers used for this study were produced in the greenhouse experiments where potato plants (cv. Satu) were fertilized with sodium selenate $\left(\mathrm{Na}_{2} \mathrm{SeO}_{4}\right.$, Sigma-Aldrich) at $0,0.00035,0.01,0.075$ and 0.9 $\mathrm{mg} \mathrm{Se} \mathrm{kg}^{-1}$ quartz sand (grain size $0.1-0.6 \mathrm{~mm}$ ). Satu is a Finnish middle early cultivar with early bulking, strong dormancy, and with the low sprouting sensitiveness. The relative rate of physiological ageing of Satu is low (Pietilä 2000). The plants were grown in individual 10-1 plastic pots containing 10 $\mathrm{kg}$ of quartz sand. Plates were placed under pots. Before planting, modified Hoagland and Arnon nu- trient solution and $7 \mathrm{~g}$ dolomite per pot were mixed into quartz sand. Sodium selenate was dissolved in deionized water and mixed into the quartz sand as well. The control plants were treated with the deionized water. The plants were fertilized second time 8 weeks after planting. There were 15 plants for each Se treatment. The plants were arranged in a completely randomized block design with three replicates. This design arrangement was chosen because of a size of the greenhouse department. The potato plants were grown under greenhouse conditions at $20-25 / 16^{\circ} \mathrm{C}$ (day/night), and a 16/8 h day/night photoperiod and at $50 \%$ relative humidity. The light intensity was controlled by shading curtains to maintain the photon flux density at approximately $220 \mu \mathrm{mol}$ photons $\mathrm{m}^{-2}$ $\mathrm{s}^{-1}$. Natural daylight was supplemented with 400 W high-pressure sodium lamps (Lucalox, LU400/ $\mathrm{HO} / \mathrm{T} / 40 \mathrm{NG}$, Hungary). Each plant was watered twice a day with automatic drip irrigation system. Tubers were harvested 16 weeks after planting and were stored at $4{ }^{\circ} \mathrm{C}$ and $75 \%$ relative humidity. The storage temperature sum (degree-days, $\mathrm{dd})>0{ }^{\circ} \mathrm{C}$ was calculated $\left(4^{\circ} \mathrm{C}-0{ }^{\circ} \mathrm{C}\right)$. The tuber age was reported as months in storage.

\section{Duration of dormancy}

The duration of dormancy of the Se-enriched seed tubers was evaluated. Dormancy was considered to end when in $80 \%$ of seed tubers one $2 \mathrm{~mm}$ long vigorous sprout was observed after 2 weeks under the sprouting conditions.

\section{Growth of sprouts}

For measurements, six seed tubers were taken from each Se treatment after 3, 4, 6 or 8 months of storage and sprouted in the egg-trays under controlled environmental conditions with a temperature of $14^{\circ} \mathrm{C}$ day/night, 16/8-hour light/dark period, a relative humidity of $70 \%$ and at a photon flux density of $30 \mu \mathrm{mol} \mathrm{m} \mathrm{m}^{-2} \mathrm{~s}^{-1}$. The accumulated temperature sum (degree-days, dd) $>4^{\circ} \mathrm{C}$ was calculated $\left(14^{\circ} \mathrm{C}-4^{\circ} \mathrm{C}\right.$ ). 
Vol. 17 (2008): 278-288.

Tubers were sprouted for 80 days (corresponding $800 \mathrm{dd}$ ). The effect of Se enrichment on the growth of sprouts was assessed on the basis of their number and length. Sprouting capacity was estimated by calculating the number of developed sprouts as a percentage of the total sprout number for each tuber (\%). Number of sprouts for each tuber was calculated according to their length; $<1 \mathrm{~cm}$ and $\geq 1 \mathrm{~cm}$. Change in fresh weight loss (\%) of tubers during sprouting was determined.

\section{Growth vigour of seed tubers in greenhouse experiments}

After recording of sprout growth, tubers from each Se treatment were planted individually in 10-1 plastic pots containing limed ( $\mathrm{pH} \mathrm{5.9)}$ and fertilized peat (Kekkilä B2, Finland). The plants were arranged in a completely randomized design with six replicates. The design arrangement was chosen because of a size and a number of greenhouse tables in the greenhouse room. The plants were grown at $22-25 / 16^{\circ} \mathrm{C}$ (day/night), in a 16-hour photoperiod at a relative humidity of $50 \%$. The light intensity was controlled by shading curtains to maintain the photon flux density of ca. $220 \mu \mathrm{mol}$ photons $\mathrm{m}^{-2} \mathrm{~s}^{-1}$. Natural daylight was supplemented with $400 \mathrm{~W}$ high-pressure sodium lamps (Lucalox, LU400/HO/T/40 NG, Hungary). Impact of Se enrichment on the early growth vigour of the seed tubers was estimated by calculating the days from planting to seedling emergence and from planting to the beginning of flowering. The seedling was considered to be emerged when the first visible green plant parts were observed. The accumulated temperature sum $>4^{\circ} \mathrm{C}$ was calculated during the growth period in a greenhouse. Tubers were harvested 16 weeks after planting. The growth vigour of seed tubers was measured by determining yield, number of main stems, tuber weight and number of tubers per plant. The number of tubers per main stem was also calculated. Only tubers of $\geq 2 \mathrm{~g}$ weight were included in the calculations.

\section{Chemical analyses}

Malondialdehyde (MDA) and starch were determining from tubers taken directly from storage after 3, 6 and 8 months or after sprouting for 88 days $(880 \mathrm{dd})$ under conditions similar to those described above. The soluble sugars were analyzed after 3 and 8 months of storage. The free putrescine, spermidine and spermine levels were determined from tubers stored for 8 months. Lipid peroxidation in tubers was determined by analysing the concentration of MDA, a product of lipid peroxidation, by the thiobarbituric acid reaction substances (TBARS) assay (Kumar and Knowles 1993). The concentration of soluble sugars was determined using the Athrone method (Yemm and Willis 1954). Starch concentration was determined using a modified method of Volenec et al. (1991) and Palonen (1999), described in Turakainen et al. (2004). In each Se treatment, analyses of MDA, soluble sugars and starch tubers at each sampling time were carried out with two potatoes (50-60 g) from three replicates. Tubers were split for analysis, frozen in liquid nitrogen and stored at $-20^{\circ} \mathrm{C}$ until lyophilization. The lyophilized samples were ground in a sample mill $(0.5-\mathrm{mm}$ mesh) (Cyclotec Sample Mill 1093, Foss Tecator, Höganäs, Sweden). Free putrescine, spermidine and spermine levels in the frozen tuber tissue samples were monitored using modification of a procedure described by Smith and Davies (1985) and Sarjala and Kaunisto (1993). For extraction, three longest sprouts from the tubers were taken with three replicates from each Se treatment. The total fresh weight of sprouts of each Se treatment was on the average $0.6 \mathrm{~g}$. Polyamines were extracted in $5 \%(\mathrm{v} / \mathrm{v}) \mathrm{HClO}_{4}$ and centrifuged at $14,750 \mathrm{~g}$ for $30 \mathrm{~min}$. Aliquots $(200 \mu \mathrm{l})$ of $\mathrm{HClO}_{4}$ extract were incubated overnight with $400 \mu$ of dansyl chloride ( $5 \mathrm{mg} \mathrm{ml}^{-1}$ of acetone) and $200 \mu \mathrm{l}$ of saturated $\mathrm{Na}_{2} \mathrm{CO}_{3}$. Polyamine standards (purchased from Sigma Co., St Louis, MO, USA) were treated in the same way. Dansylated polyamines were dissolved in methanol and separated with high pressure liquid chromatography (HPLC) (Merck Hitachi Model, Japan) by using a LiChroCART 125-4 LiChrospher 100 RP-18 5- $\mu \mathrm{m}$ 
Turakainen, M. et al. Impact of selenium enrichment on seed potato tubers

column, a methanol-water gradient and fluorescence spectrophotometry (Merck Hitachi F-1050) for determination of polyamine concentrations as described by Sarjala and Kaunisto (1993).

\section{Statistical analysis}

The statistical analyses were carried out using SAS System for Windows V9.1 (SAS Institute Inc. 2000-2003. Cary, NC, USA). Data were tested using analysis of variance in the GLM procedure. Significantly different means among Se treatments were made using Tukeys's Studentized Range (HSD) Test. Differences among means were considered significant at $p \leq 0.05$.

\section{Results}

\section{Selenium concentration of seed tubers}

As previously reported by Turakainen et al. (2006), the Se concentration in the seed tubers varied greatly depending on the level of Se addition to the plants in the preceding generation. It was on average $0.01,0.09,0.20,1.33$ and $16 \mu \mathrm{g} \mathrm{Se} \mathrm{g}^{-1} \mathrm{DW}$ at the Se addition levels of $0,0.0035,0.01,0.075$ and $0.9 \mathrm{mg} \mathrm{kg}^{-1}$ quartz sand, respectively.

\section{Storage studies}

\begin{abstract}
All seed tubers stored for 2 months at $4^{\circ} \mathrm{C}$ exhibited deep dormancy irrespective of the Se treatment, whereas in the tubers stored for 3 months at $4^{\circ} \mathrm{C}$, dormancy was lost during two weeks after transfer to sprouting conditions (data not shown). Increased storage time diminished fresh weight of seed tubers during sprouting (data not shown). This response was not dependent on the Se treatment.
\end{abstract}

\section{Sprouts growth and polyamine concentrations in sprouts}

As storage time increased from 2 to 8 months, the number of long $(\geq 1 \mathrm{~cm})$ sprouts per tuber and their sprouting capacity increased for all Se treatments after sprouting for 80 days at $14^{\circ} \mathrm{C}$, indicating increased loss in apical dominance (Fig. 1a, b). The maximum sprouting capacity $(100 \%)$ was achieved only for seed tubers produced with the Se treatments of 0.075 and $0.9 \mathrm{mg} \mathrm{kg}^{-1}$ (Fig. 1b). In the control tubers the maximum sprouting capacity was $73 \%$ (Fig. 1b). The highest Se treatment $(0.9$ $\left.\mathrm{mg} \mathrm{kg}^{-1}\right)$ also significantly enhanced the concentration of free putrescine in the longest sprouts of 80-day-sprouted tubers stored for 8 months (Fig. 2). However, free spermidine and spermine were not affected by Se treatments.

\section{Effect of Se on ageing of seed tubers}

MDA concentration was only slightly increased in the tubers when storage time increased from 6 to 8 months (Fig. 3a). Sprouting resulted in an increase in MDA accumulation in the tubers (Fig. $3 b)$. However, sprouting-induced increase was the smaller the longer the storage time (Fig. 3b). In the seed tubers stored for 6 months, some effect of Se was found. However, the effects were not consistent with the Se addition levels (Fig 3a).

No consistent effect of Se on the starch concentration was observed during storage and after sprouting when the seed tubers were stored for 3, 6 and 8 months (data not shown). However, starch concentration was slightly lower after sprouting. The concentration of soluble sugars declined when the storage time increased from 3 to 8 months (Fig. 4). After 8-month storage, Se did not significantly influence soluble sugars in the seed tubers (Fig. 4). 


\section{AGRICULTURAL AND FOOD SCIENCE}

Vol. 17 (2008): 278-288.
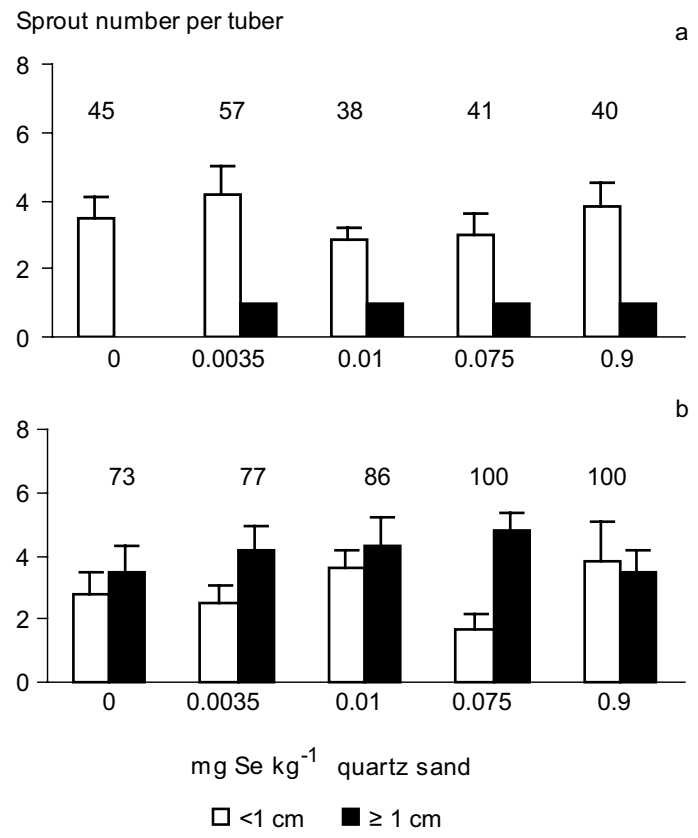

Fig. 1. Growth of spouts of potato seed tubers stored for a) 2 months and b) 8 months given as the number of growing sprouts and percentage sprouting (\%) per tuber (the values above the bars). Sprouts were categorised according to their length: $<1 \mathrm{~cm}$ and $\geq 1 \mathrm{~cm}$. Seed tubers were produced at various addition levels of $\mathrm{Se}(0,0.0035,0.01$, 0.075 and $0.9 \mathrm{mg} \mathrm{Se} \mathrm{kg}^{-1}$ quartz sand). Error bars indicate S.E., $\mathrm{n}=6$.

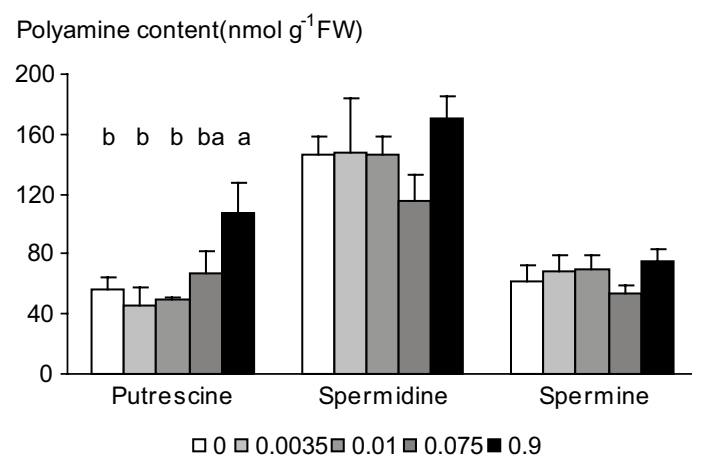

Fig. 2. Concentration of free polyamines, putrescine, spermidine and spermine nmol $\mathrm{g}^{-1}$ fresh weight $(\mathrm{FW})$ in the sprouts of potato seed tubers stored for 8 months. Seed tubers were produced at various addition levels of $\mathrm{Se}$ $\left(0,0.0035,0.01,0.075\right.$ and $0.9 \mathrm{mg} \mathrm{Se} \mathrm{kg}^{-1}$ quartz sand). Bars with different letters indicate significant differences at $p \leq 0.05$ between Se treatments. Error bars indicate S.E., $\mathrm{n}=6$.
Malondialdehyde $\left(\mathrm{nmol} \mathrm{g}^{-1} \mathrm{DW}\right)$

a
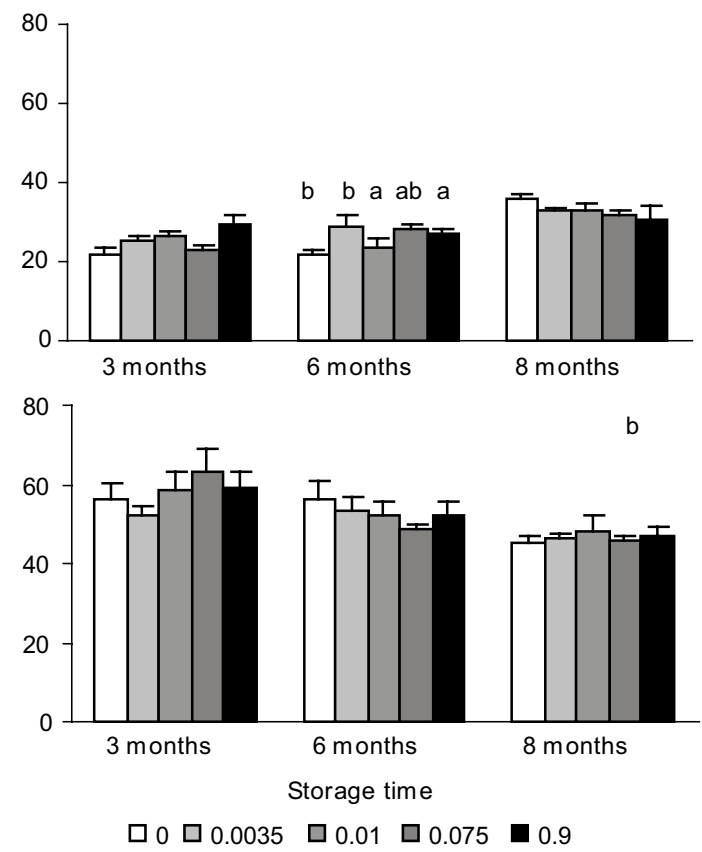

Fig. 3. Malondialdehyde concentration of potato seed tubers stored for 3, 6 and 8 months a) prior to ( 0 day) and b) after sprouting ( 88 days). Seed tubers were produced at various addition levels of Se $(0,0.0035,0.01,0.075$ and $0.9 \mathrm{mg} \mathrm{kg}^{-1}$ quartz sand). Bars with different letters indicate significant differences at $p \leq 0.05$ among Se treatments. Error bars indicate S.E., $\mathrm{n}=3$.

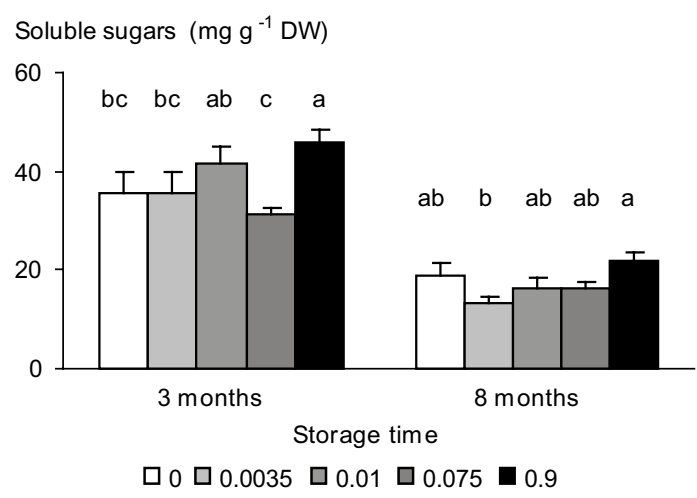

Fig. 4. Concentration of soluble sugars of potato seed tubers stored for 3 and 8 months. Seed tubers were produced at various addition levels of $\mathrm{Se}(0,0.0035,0.01$, 0.075 and $0.9 \mathrm{mg} \mathrm{kg}^{-1}$ quartz sand). Bars with different letters indicate significant differences at $p \leq 0.05$. Error bars indicate S.E., $\mathrm{n}=6$. 
Turakainen, M. et al. Impact of selenium enrichment on seed potato tubers

\section{Effect of Se-enriched seed tubers on the yield of next progeny}

In the seed tubers stored for 2 to 8 months, the rate of emergency and initiation of flowering of the potato plants were not affected by Se (data not shown). When storage time was increased from 2 to 6 months, the tuber yield almost doubled, but was not influenced by Se enrichment in the seed tuber (Table 1). The highest yield was harvested from plants produced with the seed tubers stored for 6 months with the highest accumulated degree-days in the greenhouse (Table 1).

Table 1. Number of main stems, yield, tuber weight, number of tubers per potato plant and number of tubers per main stem, indicating the growth vigour of seed tubers stored for 2, 3, 4, 6 or 8 months. Seed tubers were produced at different levels of Se $\left(0,0.0035,0.01,0.075\right.$ and $0.9 \mathrm{mg} \mathrm{kg}^{-1}$ quartz sand). Values in each column within each storage time followed by the same letter are not significantly different at $p \leq 0.05, \mathrm{n}=6$. $\mathrm{dd}=$ accumulated day-degrees.

\begin{tabular}{|c|c|c|c|c|c|c|c|}
\hline $\begin{array}{c}\text { Months in } \\
\text { storage, } \\
\text { dd during storage }\end{array}$ & $\begin{array}{l}\text { Se added, } \\
\mathrm{mg} \mathrm{kg}^{-1} \\
\text { quartz sand }\end{array}$ & $\begin{array}{l}\text { dd during } \\
\text { growth } \\
\text { period }\end{array}$ & $\begin{array}{l}\text { Main stems } \\
\text { per tuber }\end{array}$ & $\begin{array}{l}\text { Yield, } \\
\text { g per } \\
\text { plant }\end{array}$ & $\begin{array}{c}\text { Tuber } \\
\text { weight, } \\
\text { g per plant }\end{array}$ & $\begin{array}{c}\text { Tubers per } \\
\text { plant }\end{array}$ & $\begin{array}{c}\text { Tubers per } \\
\text { stem }\end{array}$ \\
\hline 2 & & 1478 & & & & & \\
\hline \multirow[t]{5}{*}{240} & 0 & & 2.5 & 651 & 50 & 13.3 & 6.4 \\
\hline & 0.0035 & & 2.2 & 655 & 52 & 13.3 & 7.3 \\
\hline & 0.01 & & 1.8 & 665 & 59 & 11.8 & 7.6 \\
\hline & 0.075 & & 2.3 & 658 & 56 & 12.5 & 5.9 \\
\hline & 0.9 & & 2.7 & 659 & 58 & 12.0 & 5.3 \\
\hline 3 & & 1463 & & & & & \\
\hline \multirow[t]{5}{*}{360} & 0 & & 2.2 & 762 & 54 & 14.7 & 8.8 \\
\hline & 0.0035 & & 2.2 & 740 & 60 & 12.7 & 6.9 \\
\hline & 0.01 & & 2.0 & 739 & 52 & 14.8 & 8.4 \\
\hline & 0.075 & & 2.3 & 733 & 60 & 12.3 & 6.7 \\
\hline & 0.9 & & 1.7 & 734 & 52 & 14.3 & 10.3 \\
\hline 4 & & 1470 & & & & & \\
\hline \multirow[t]{5}{*}{480} & 0 & & $1.7 \mathrm{~b}$ & 796 & 82 & 10.2 & 7.7 \\
\hline & 0.0035 & & $2.7 \mathrm{ab}$ & 835 & 72 & 12.2 & 4.6 \\
\hline & 0.01 & & $4.0 \mathrm{a}$ & 849 & 67 & 13.3 & 4.3 \\
\hline & 0.075 & & $2.3 \mathrm{ab}$ & 834 & 72 & 12.5 & 6.3 \\
\hline & 0.9 & & $1.8 \mathrm{~b}$ & 831 & 74 & 11.3 & 7.7 \\
\hline 6 & & 1573 & & & & & \\
\hline \multirow[t]{5}{*}{720} & 0 & & 1.8 & 1226 & $92^{\mathrm{a}}$ & 14.0 & 7.9 \\
\hline & 0.0035 & & 2.3 & 1263 & $82^{\mathrm{ab}}$ & 15.7 & 9.4 \\
\hline & 0.01 & & 3.0 & 1306 & $82^{\mathrm{ab}}$ & 16.7 & 6.9 \\
\hline & 0.075 & & 2.4 & 1243 & $70^{b}$ & 18.5 & 8.5 \\
\hline & 0.9 & & 2.4 & 1229 & $82^{\mathrm{ab}}$ & 15.2 & 8.0 \\
\hline 8 & & 1485 & & & & & \\
\hline \multirow[t]{5}{*}{960} & 0 & & 3.3 & 1074 & 67 & 17.2 & 6.5 \\
\hline & 0.0035 & & 3.5 & 1029 & 67 & 16.0 & 5.2 \\
\hline & 0.01 & & 3.7 & 1092 & 64 & 16.7 & 5.1 \\
\hline & 0.075 & & 3.8 & 1109 & 67 & 17.2 & 4.8 \\
\hline & 0.9 & & 5.2 & 1129 & 70 & 16.7 & 4.1 \\
\hline
\end{tabular}




\section{AGRICULTURAL AND FOOD SCIENCE}

Vol. 17 (2008): 278-288.

\section{Discussion}

In the present study, the positive effect of Se on the growth of sprouts of seed tubers became evident in the tubers stored for 8 months at $4^{\circ} \mathrm{C}$; the sprouting capacity reached the peak value at Se levels of 0.075 and $0.9 \mathrm{mg} \mathrm{kg}^{-1}$. The highest putrescine concentration that was measured at the level of 0.9 mg Se $\mathrm{kg}^{-1}$ after 8 months of storage may indicate that the high Se enrichment affect positively either on the putrescine synthesis or sprouts may reflect different stage of development.

Previous studies have shown an increased accumulation of lipid peroxidation products such as MDA in the potato tubers as tuber age increased from 10 to 30 months at $4{ }^{\circ} \mathrm{C}$ (Kumar and Knowles 1993). In the present study, the elevated MDA during prolonged storage for 8 months at 4 ${ }^{\circ} \mathrm{C}$ and after sprouting provided evidence that lipid peroxidation occurred. However, the Se enrichment in the seed tubers had no consistent effect on the accumulation of MDA. At the highest Se enrichment level, the Se concentration of tubers was on average $16 \mu \mathrm{g} \mathrm{g}^{-1} \mathrm{DW}$. We did expect that at this level Se would induce lipid peroxidation in the tubers. In a previous study of Cartes et al. (2005), the Se concentration above $20 \mu \mathrm{g} \mathrm{g}^{-1} \mathrm{DW}$ in ryegrass enhanced lipid peroxidation. In the present study, the starch concentration remained constant, but that of soluble sugars decreased during storage for 3 to 8 months, irrespective of the Se level, which agrees with the results of Kumar and Knowles (1993). However, during sprouting the starch concentration slightly diminished. Even though this indicates that some starch was degraded, the contribution of this process to sprout growth was not seen. This phenomenon is evident in physiologically aged tubers (Mikitzel and Kumar 1989a, Spychalla and Desborough 1990).

Although Se enrichment of seed tuber did not have significant effect on the next progeny yields, in the present study a 6-month storage period was optimal in terms of growth vigour of seed tubers. Probably after 8 months of storage, the optimum physiological age of the seed tubers for yield production was passed and they had lost some of their growth vigour, which was reflected as lower yields and smaller tuber sizes. It should be noted that the tubers that generated the highest yields had been stored for optimal 6 months but, in addition, during the greenhouse cultivation their accumulated degree-days raised approximately $100 \mathrm{dd}$ higher than those of the tubers stored for longer or shorter periods (Table 1).

In contrast to earlier results (Xue et al. 2001, Djanaguiraman et al. 2005) showing an effective antioxidative role of Se delaying the senescence of lettuce and soybean leaves, no antioxidative effects of Se could been found in potato seed tubers in the present study. However, it is noteworthy that potato is analytically a very challenging species because individual tubers from a given plant can vary in chemical composition. When studying relatively small effects of the Se treatments on the physiological ageing processes, a large number of tubers and replications are required. In addition, the seed tubers should be aged more.

In conclusion, the high Se enrichment had some positive effects on the growth of sprouts, but it had no consistent effect on the growth vigour of seed potato tubers. Irrespective of the Se treatment, the highest yield was harvested from plants produced with seed tubers stored for 6 months. Further studies with physiologically older tubers than those investigated in the present study are needed to unravel the effects of Se on growth vigour as related to ageing processes in potato seed tubers

Acknowledgements. We thank Aira Vainiola and Juha Kärkkäinen for technical assistance and Markku Tykkyläinen for assistance in the greenhouse. This work was supported by the Agricultural Research Foundation of Tiura and the University of Helsinki.

\section{References}

Asiedu, S.K., Astatkie, T. \& Yiridoe, E.K. 2003. The effect of seed-tuber physiological age and cultivar on early potato production. Journal of Agronomy and Crop Science 189: 176-184.

Bouchereau, A., Aziz, A., Larher, F. \& Martin-Tanguy, J. 1999. Review. Polyamines and environmental challeng- 
Turakainen, M. et al. Impact of selenium enrichment on seed potato tubers

es: recent development. Plant Science 140: 103-125.

Burton. W.G. 1989. The Potato. 3rd ed. New York: John Wiley \& Sons, Inc. 742 p.

Caldiz, D.O., Fernandez, L.V. \& Struik, P.C. 2001. Physiological age index: a new, simple and reliable index to assess the physiological age of seed potato tubers based on haulm killing date and the length of the incubation period. Field Crops Research 69: 69-79.

Cartes, P., Gianfreda, L. \& Mora, M.L. 2005. Uptake od selenium and its andioxidant activity in ryegrass when applied as selenate and selenite forms. Plant and Soil 276: 359-367.

Cottrell, E., Duffus, C.M., Paterson, L., Mackay, G.R., Allison, M.J. \& Bain, H. 1993. The effect of storage temperature on reducing sugar concentration and the activities of three amylolytic enzymes in tubers of the cultivated potato, Solanum tuberosum L. Potato Research 36: 107-117.

Djanaguiraman, M., Devi, D.D., Shanker, A.K., Sheeba, A. \& Bangarusamy, U. 2005. Selenium - an antioxidative protectant in soybean during senescence. Plant and Soil 272: 77-86.

Gladyshev, V.N. \& Hatfield D.L. 1999. Review. Selenocysteine-containing proteins in mammals. Journal of Biomedical Science 6: 151-160.

Hartikainen, H. \& Xue, T. 1999. The promotive effect of selenium on plants growth as triggered by ultraviolet irradiation. Journal of Environmental Quality 28: 1372-1375.

Hartikainen, H., Xue, T. \& Piironen, V. 2000. Selenium as an anti-oxidant and pro-oxidant in ryegrass. Plant and Soil 225: 193-200.

Hartmans, K.J., \& van Loon, C.D. 1987. Effect of physiological age on growth vigour of seed potatoes of two cultivars. 1. Influence of storage period and temperature on sprouting characteristics. Potato Research 30: 397-409.

Kaur-Sawhney, R., Shih, L-M. \& Galston, A.W. 1982. Relation of polyamine biosynthesis to the initiation of sprouting in potato tubers. Plant Physiology 69: 411-415.

Knowles, R.N. \& Botar, G.I. 1992. Effect of altering the physiological age of seed-tubers in the fall on subsequent production in a short-season environment. Canadian Journal of Plant Science 72: 275-287.

Knowles, N.R. \& Knowles, L.O. 1989. Correlation between electrolyte leakage and degree of saturation of polar lipids from aged potato (Solanum tuberosum L.) tuber tissue. Annals of Botany 63: 331-338.

Kong, L., Wang, M. \& Bi, D. 2005. Selenium modulates the activities of antioxidant enzymes, osmotic homeostasis and promotes the growth of sorrel seedlings under salt stress. Plant Growth Regulation 45: 155-163.

Kumar, M.G.N. \& Knowles, R.N. 1993. Changes in lipid peroxidation and lipolytic and free-radical scavenging enzyme activities during aging and sprouting of potato (Solanum tuberosum) seed-tubers. Plant Physiology 102: 115-124.

Kumar, R.N. \& Botar, G.I. 1992. Effect of altering the physiological age of the potato seed-tubers in the fall on the subsequent production in a short-season environment. Canadian Journal of Plant Science 72: 275-287.

Kumar, M.G.N. \& Knowles, R.N. 1996. Oxidative stress results in increased sinks for metabolic energy during ag- ing and sprouting on potato seed-tubers. Plant Physiology 112: 1301-1313.

Martin-Tanguy, J. 2001. Metabolism and function of polyamines in plants: resent development (new approaches). Plant Growth Regulation 34: 135-148.

Mikitzel, L.J. \& Knowles, N.R. 1989a. Polyamine metabolism of potato seed-tubers during long-term storage and early sprout development. Plant Physiology 91: 183-189.

Mikitzel, L.J. \& Knowles, N.R. 1989b. Potato seed-tuber age affects mobilization of carbohydrate reserves during plant establishment. Annals of Botany 63: 311-320.

Mikitzel, L.J. \& Knowles, N.R. 1990. Changes in respiratory metabolism during sprouting of aged seed-potato tubers. Canadian Journal of Botany 68: 1619-1626.

O'Brien, P.J., Allen, E.J., Bean, J.N., Griffith, R.J., Jones, S.A. \& Jones, J.L. 1983. Accumulated day degrees as a measure of physiological age and the relationships with growth and yield in early potato varieties. Journal of Agricultural Science 101: 613-631.

Palonen, P. 1999. Relationship of seasonal changes in carbohydrates and cold hardiness in canes and buds of three red raspberry cultivars. Journal of American Society for Horticultural Science 124: 507-513.

Pennanen, A., Xue, T. \& Hartikainen, H. 2002. Protective role of selenium in plant subjected to severe UV irradiation stress. Journal of Applied Botany 76: 66-76.

Pietilä, Leena 2000. Boreal Research Report 14. Satu potato. Boreal Plant Breeding Ltd. 10 p. In Finnish.

Rani, N., Dhillon, K.S. \& Dhillon, S.K. 2005. Critical levels of selenium in different crops grown in an alkaline silty loam soil treated with selenite-Se. Plant and Soil 277: 367-374.

Rotruck, J.T., Pope, A.H., Ganthe, H.E., Swanson, A.B., Hafeman, D.G. \& Hoekstra, W.G. 1973. Selenium: Biochemical role as a component of glutathione peroxidase. Science 179: 588-590.

Sarjala, T. \& Kaunisto, S. 1993. Needle polyamine concentrations and potassium nutrition in Scots pine. Tree Physiology 13:87-96.

Schwartz, K. \& Foltz, C. 1957. Selenium as an integral part of factor 3 against dietary necrotic liver degradation. Journal of American Chemical Society 79: 3292-3293.

Seppänen, M., Turakainen, M. \& Hartikainen, H. 2003. Selenium effects on oxidative stress in potato. Plant Science 165: 311-319.

Smith, M.A. \& Davies, P.J. 1985. Separation and quantification of polyamines in plant tissue by high performance liquid chromatography of their dansyl derivatives. Plant Physiology 78: 89-91.

Spychalla, J.P. \& Desborough, S.L. 1990. Fatty acids, membrane permeability, and sugars of stored potato tubers. Plant Physiology 94: 1207-1213.

Struik, P.C. \& Wiersema, S.G. 1999. Seed Potato Technology. Netherlands, Wageningen Pers, Wageningen. $383 \mathrm{p}$.

Turakainen, M., Hartikainen, H. \& Seppänen, M.M. 2004a. Effects of selenium treatments on potato (Solanum tuberosum L.) growth and concentrations of soluble sugars and starch. Journal of Agricultural and Food Chemistry 52: 5378-5382.

Turakainen, M., Väänänen, T. Anttila, K., Ollilainen VM., 


\section{AGRICULTURAL AND FOOD SCIENCE}

Vol. 17 (2008): 278-288.

Hartikainen, H. \& Seppänen M. 2004b. Effect of selenate supplementation on glycoalkaloid content of potato (Solanum tuberosum L.). Journal of Agricultural and Food Chemistry 52: 7139-7143.

Turakainen, M., Hartikainen, H., Ekholm, P. \& Seppänen, M.M. 2006. Distribution of selenium in different biochemical fractions and raw darkening degree of potato (Solanum tuberosum L.) tubers supplemented with selenate. Journal of Agricultural and Food Chemistry 54: 8617-8622

White, P.J., Bowen, H.C., Parmaguru, P., Fritz, M., Spracklen, W.P., Spidy, R.E., Meacham, M.C., Mead, A., Harriman, M., Trueman, L.J., Smith, B.M., Thomas, B. \& Broadley, M.R. 2004. Interactions between selenium and sulphur nutrition in Arabidopsis thaliana. Journal of Experimental Botany 55: 1927-1937.

Van der Zaag, D.E. \& van Loon, C.D. 1987. Effect of physiological age on growth vigour of seed potatoes of two cultivars. 5. Review of literature and integration of some experimental results. Potato Research 30: 451-472.

Van Ittersum, M.K. 1992. Dormancy and vigour of seed potatoes. PhD thesis, Wageningen Agricultural University, Wageningen, the Netherlands.

Volenec, J.J., Boyce, P.J. \& Hendershot, K.L. 1991. Carbohydrate metabolism in taproots of Medicago sativa L. during winter adaptation and spring growth. Plant Physiology 96: 786-793.

Xue, T. \& Hartikainen, H. 2000. Association of antioxidative enzymes with synergistic effect of selenium and UV irradiation in enhancing plant growth. Agricultural and Food Science in Finland 9: 177-186.

Xue, T., Hartikainen, H. \& Piironen, V. 2001. Antioxidative and growth-promoting effect of selenium in senescing lettuce. Plant and Soil 27: 55-61

Yemm, E.W. \& Willis, A.J. 1954. The estimation of carbohydrates in plants extracts by anthrone. Biochemical Journal 57: 508-514. 
Turakainen, M. et al. Impact of selenium enrichment on seed potato tubers

\title{
SELOSTUS
}

\section{Seleenirikastuksen vaikutus siemenperunaan}

\author{
Marja Turakainen, Helinä Hartikainen, Tytti Sarjala ja Mervi M. Seppänen \\ Helsingin yliopisto ja Metsäntutkimuslaitos
}

\begin{abstract}
Suomessa perunaa joudutaan varastoimaan pitkään. Varastoinnin aikana siemenperunassa tapahtuu fysiologisia ja biokemiallisia muutoksia, jotka johtavat hiljalleen fysiologiseen vanhenemiseen ja sitä kautta mukulan elinvoiman ja sadonmuodostuskyvyn alenemiseen. Seleeni $(\mathrm{Se})$ on välttämätön alkuaine ihmisten ja eläinten terveydelle. Viljelykasvien ei ole katsottu välttämättä tarvitsevan seleeniä. Kuitenkin pienen seleenilisäyksen on havaittu lisäävän kasvien antioksidatiivista kapasiteettia, parantavan kasvien kasvua, satoa ja laatua sekä hidastavan kasvien vanhenemista.

Helsingin yliopistossa Soveltavan biologian laitoksella tutkittiin voiko seleeni edistää siemenperunan elinvoiman säilymistä sekä hidastaa vanhenemista varastoinnin aikana. Seleenirikastetut siemenperunat tuotettiin edellisenä kasvukautena kasvihuoneessa kasveissa, jotka kasvatettiin nousevilla seleenimäärillä $(0,0.0035,0.01$, 0.075 ja $0.9 \mathrm{mg} \mathrm{Se} \mathrm{kg}^{-1}$ ) lannoitetussa kvartsihiekassa, joilla siemenperunoiden seleenipitoisuudet olivat keskimäärin $0.01,0.09,0.20,1.33$ and $16 \mu \mathrm{g} \mathrm{Se} \mathrm{g}^{-1}$ kuivapainoa, tässä järjestyksessä.

Seleenin vaikutusta siemenperunan itujen kasvuun tutkittiin määrittämällä itujen lukumäärä ja itämiskapasiteetti. Iduista määritettiin vapaiden polyamiinien
\end{abstract}

pitoisuus. Malondialdehydin (MDA) ja liukoisten sokereiden kertyminen sekä tärkkelyksen hajoaminen määritettiin siemenperunoista varastoinnin aikana. Siemenperunoiden elinvoima tutkittiin kasvihuonekokeissa määrittämällä taimettumisaika, kukinnan alkamisaika, pääversojen lukumäärä sekä kasvikohtaisesti sato, mukulalukumäärä ja mukulapaino.

Tutkimuksen tulokset osoittivat, että korkeimmat seleenilisäykset $\left(0.075 \mathrm{ja} 0.9 \mathrm{mg} \mathrm{kg}^{-1}\right)$ paransivat itämiskapasiteettia eli suurempi osa olemassa olevista iduista oli lähtenyt kasvuun. Korkeimmalla seleenirikastuksella oli positiivinen vaikutus itujen vapaan putreskiinin pitoisuuteen. Lisääntynyt itujen kasvu ei ollut yhteydessä siemenperunoiden elinvoimaan eli tuotetun sadon määrään. Seleenirikastuksella ei ollut vaikutusta perunoiden MDA:n eikä liukoisten sokereiden kertymiseen eikä tärkkelyksen hajoamiseen. Korkein sato tuotettiin kuusi kuukautta varastoidulla siemenperunalla, riippumatta seleenilisäyksestä. Kahdeksan kuukautta varastoidut siemenperunat sen sijaan tuottivat alhaisemman sadon, mikä viittaa siihen, että siemenperunan optimaalinen ikä oli jo ohitettu. Tulokset osoittavat, että seleenirikastuksella ei ollut selvää siemenperunoiden vanhenemista hidastavaa eikä niiden elinvoimaa edistävää vaikutusta. 